\title{
Hands-On Open Access Broadband Wireless Technology Lab
}

\author{
Mapping Course Outcomes to Lab Experiments \\ http://dx.doi.org/10.3991/ijim.v6i4.2161 \\ Yazan A. Alqudah ${ }^{1}$, Todor Cooklev ${ }^{2}$ \\ ${ }^{1}$ Princess Sumaya University for Technology Amman, Jordan \\ ${ }^{2}$ Indiana University Purdue University, Fort Wayne, Indiana
}

\begin{abstract}
The unprecedented growth in wireless communication is offering opportunities and challenges for educators. Thanks to technology advances and job opportunities, more and more students are interested in wireless communications courses. However, bridging the gap between classroom and real-world experience remains a challenge. Advanced undergraduate communications courses typically focus more on theory. Some courses are given online, and lack hands-on experiments. Driven by feedback from industry and students, we propose practical laboratory experiments that attempt to bridge the gap between classroom and real world. The laboratory exercises take advantage of the infrastructure of deployed wireless networks and allow students to measure, and analyze data, as well as to interact. The proposed labs can be used even in online courses. This paper describes the experiments proposed, the procedures and typical results. The experiments are tied to course objective.
\end{abstract}

Index Terms-component; Open Access Lab, Field Measurements Experiments, Broadband Wireless, WiMAX, Path Loss, Propagation Models, and Throughput.

\section{INTRODUCTION}

Mobile wireless communications technology has witnessed unprecedented popularity and penetration in the last decade. There are an estimated 6.5 billion mobile users around the world. With the popularity of wireless access comes the demand for higher data rate and ubiquitous access. Equipment manufacturers and service providers have been introducing technologies to keep up with user voice and data demands. A technology that has gained worldwide adoption for wireless broadband access is WiMAX (Wireless Interoperability for Microwave Access [1]). The technology has been adopted faster in some developing countries to bridge the digital divide and give population internet access. The WiMAX technology has taken advantage of years of advances in research and incorporates the latest technologies and algorithms in its Physical and MAC layers.

The main objective of engineering education is to prepare students to enter the workforce by providing classroom and laboratory knowledge needed to analyze and design complex engineering problems. Recently, a gap is developing in the teaching of wireless communication technology. As the technology advances at an unprecedented rate, most schools are finding hard to keep up with latest technologies in their curriculum and laboratory work. This is due to the rapid pace at which new technologies are introduced, the lack and high-cost of laboratory equipment. Furthermore, some courses are given online and completely lack a hands-on component.

Several educators have taken the responsibility to fill the gap in wireless communications and tie theory to practical real- world problems. In [2], a project-based approach is proposed using Wi-Fi modules. Spread spectrum wireless laboratory is proposed in [3]. The use of optical wireless (infrared) is presented in [4]. A low cost field programmable gate array (FPGA) is discussed in [5]. Wireless sensors design based course is proposed [6]. Other published work focuses on Radio Frequency (RF) and Microwave [7], and antennas [8].

While lab exercises for online courses do exist, these labs are always online, "virtual" labs that simulate certain aspects of practical wireless systems. For example, there are several software systems that model RF propagation, wireless networking, physical layer signal processing, etc. Such software is available through OPNET $^{\mathbb{B}}$, Matlab ${ }^{\circledR}$, etc. Educators generally accept that even though it is desirable, it is not possible to have a hands-on lab as part of an online course; this is considered as one of the major weaknesses of online education.

The objective of this work is to bridge the gap between the academic education and real world by developing an open-access wireless lab that takes advantage of current deployed wireless and cellular networks and enables students to perform experiments in the field by collecting and observing measurements. The students will be responsible for analyzing the data obtained by their group and interact with other student groups to reinforce theory covered in the course.

This series of experiments is based on a deployed WiMAX network to reinforce theory covered in the classroom including: broadband $4 \mathrm{G}$ technology, cellular concepts, cell size, and interference, propagation models, the impact of signal strength, obstacles, and environment on received signal strength, adaptive modulation and dependence on signal strength, data throughput for voice, data and video traffic and dependence on link quality.

The experiments are to be carried out by separate student groups. Note that the results of each group might vary depending on the environment in which the experiments were performed. As a result, the students will be given an opportunity to compare and contrast their results with other groups by uploading their data to a central 
server. In this way the developed labs foster peer-learning, which we believe is an important pedagogical tool. In the peer-learning process, students learn with and from each other. Indeed, one of the best ways to learn and understand something is to explain it to someone else.

The choice of WiMAX as wireless standard for the lab is motivated by several factors:

- WiMAX is a mature technology with world-wide adoption. This is especially true in some developing and rural areas.

- The ability of the technology to provide access with minimal overhead and set up by users.

- Easy access to CPE link parameters through a PC. This enables students to capture information needed to complete experiments.

- The large coverage area of WiMAX cell enables exercising various channels conditions.

- The abundance of literature and textbooks that describe different aspects of the technology enables students and educators to have a thorough understanding of the concepts.

This paper is organized as follows: In section II, we review course objective and coverage. In section III, we describe experiments procedures and typical results. Finally, the conclusion and observations are presented in section III.

\section{COURSE COVERAGE AND OBJECTIVES}

Wireless courses taught at senior undergraduate level build on fundamentals learned in senior-level communications and data networking courses. Furthermore, the students would have been already exposed to some of the wireless technical terms and themes such as WiMAX, GSM, HSDPA, 4G, broadband, CDMA, etc. The students familiar with these technical terms expect that a wireless course will help them understand cellular concepts and technology. However, it is the case that often textbooks fall behind on real-world advances in this field. With the introduction of WiMAX and LTE in the last decade and the advent of a new generation of wireless technology every 4-5 years, it is not surprising that instructors and students find information in textbooks obsolete.

This section reviews and introduces fundamental concepts that are covered by senior level wireless courses. The next section will tie these concepts with proposed field experiments.

\section{A. Cellular Network Concept}

The cellular concept is fundamental in understanding coverage, performance and implementation of a wide area network. The idea behind a cellular network is to divide a coverage area into smaller adjacent, non overlapping areas, called cells. Each cell is served by a transceiver or base station. To increase capacity and reduce power requirements, the overall spectrum allocated for the network is divided in small pieces that can be assigned to each cell. This enables the reuse of the spectrum in adjacent group of cell granted that any carrier frequency is used at farthest cell in the group. The concept of a cellular network is illustrated in Fig. 1.

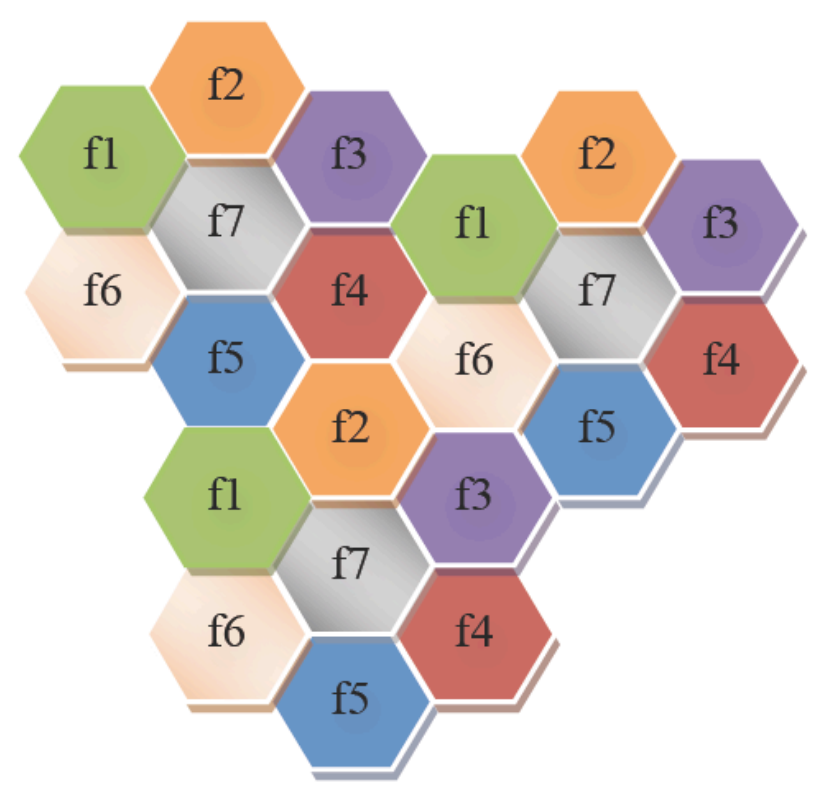

Figure 1. Cellular network diagram

Cellular networks offer higher capacity, reduced power usage, and reduce interference from adjacent users and cells. Most wireless technologies with wide area coverage rely on the cellular concept to serve their users. This is particularly true for WiMAX.

\section{B. Wave propagation and propagation models}

Wave propagation and propagation models are fundamental concepts taught in wireless courses. Wave propagation deals with the electromagnetic wave as is it travels between transmitter (base station) and receiver (mobile phone). As the wave travels, it is impacted by the environment. The wave undergoes reflection, diffraction, and scattering. Large scale propagation models attempt to predict average signal power for arbitrary transmitter/receiver separation and environment. These models are critical in planning and deploying a cellular network as they can predict cells performance and coverage for different base station locations. Due to the complexity in predicting received signal strength, propagation models rely on statistical modeling based on field measurements. [9]-[19].

The models are summarized in Table I. The Free Space (FS) path loss is an analytical model that predicts the strength of the signal received when a clear line of sight path exists between transmitter and receiver. The FS model does not account for multipath propagation and cannot be used for point-multipoint radio link. It is included however include it here as a reference. The Stanford University Interim (SUI) is an empirical model recommended by standardizing committee. The constants $\mathrm{a}, \mathrm{b}$ and $\mathrm{c}$ depend on the terrain and are given in Table II. The model contains frequency and height correction factors. The ECC-33 also known as Hata-Okumura extended model is based on Okumura model and is extended original model to frequencies up to $3.5 \mathrm{GHz}$. The COST231 model is an extension to the Hata-Okumura model that has a correction factor for environment. The 
PAPER

Hands-On Open Access Broadband Wireless Technology Lab: Mapping Course Outcomes to Lab Experiments

TABLE I.

SUMMARY OF PROPAGATION MODELS.

\begin{tabular}{|c|c|c|c|c|c|}
\hline \multicolumn{6}{|l|}{ Model } \\
\hline Free Space & \multicolumn{5}{|c|}{$P L_{F S}=32.45+20 \log _{10}(d)+20 \log _{10}(f)$} \\
\hline \multirow[t]{5}{*}{$802.16 \mathrm{SUI}$} & \multicolumn{5}{|c|}{$\begin{array}{l}P L_{S U I}=A+10 \gamma \log _{10}\left(\frac{d}{d_{0}}\right)+X_{f}+X_{h}+s \\
A=20 \log _{10}\left(\frac{4 \pi d_{0}}{\lambda}\right) \\
\gamma=a-b h_{b}+\left(\frac{c}{h_{b}}\right) \\
X_{f}=6.0 \log 10\left(\frac{f}{2000}\right) \\
X_{h}= \\
\left\{\begin{array}{l}-10.8 \log _{10}\left(\frac{h_{r}}{2000}\right), \quad \text { for terrian } A \text { and } B \\
-20.0 \log _{10}\left(\frac{h_{r}}{2000}\right), \quad \text { for terrian } C\end{array}\right\} \\
\mathrm{d}_{0}=100 \mathrm{~m}\end{array}$} \\
\hline & Parameter & $\begin{array}{l}\text { errain } \\
\text { illy) }\end{array}$ & \multicolumn{2}{|c|}{\begin{tabular}{l|}
$\begin{array}{l}\text { Terrain B } \\
\text { (flat) }\end{array}$ \\
\end{tabular}} & $\begin{array}{l}\text { Terrain C } \\
\text { (rare } \\
\text { vegeta- } \\
\text { tions) }\end{array}$ \\
\hline & $\mathrm{a}$ & 4.6 & \multicolumn{2}{|l|}{4.0} & 3.6 \\
\hline & $\mathrm{b}$ & 0.0075 & \multicolumn{2}{|l|}{0.0065} & 0.005 \\
\hline & & 12.6 & \multicolumn{2}{|c|}{17.1} & 20 \\
\hline ECC-33 & \multicolumn{5}{|c|}{ 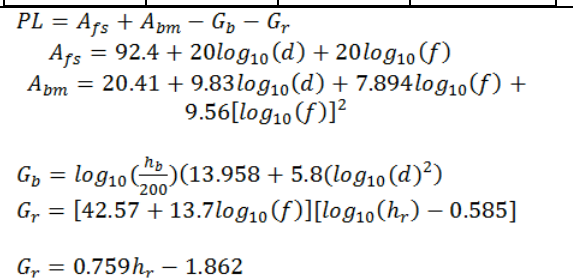 } \\
\hline COST & \multicolumn{5}{|c|}{$\begin{array}{c}G_{r}=0.139 h_{r}-1.862 \\
\quad-a h_{m} \\
+\left(44.9-6.55 \log _{10}\left(h_{b}\right)\right) \log _{10} d+c_{m} \\
a h_{m}=3.20\left(\log _{10}\left(11.75 h_{r}\right)\right)^{2}-4.79 \\
a h_{m}=\left(1.11 \log _{10} f-0.7\right) h_{r}-\left(1.5 \log _{10} f-0.8\right.\end{array}$} \\
\hline \multirow[t]{5}{*}{ Ericsson } & \multicolumn{5}{|c|}{$\begin{array}{c}P L=a_{0}+a_{1} \log _{10}(d)+a_{2} \log _{10}\left(h_{b}\right) \\
+a_{3} \log _{10}\left(h_{b}\right) \log _{10}(d) \\
-3.2\left(\log _{10}\left(11.75 h_{r}\right)^{2}\right)+g(f) \\
g(f)=44.49 \log _{10}(f)-4.78\left(\log _{10}(f)\right)^{2}\end{array}$} \\
\hline & Parameter & $\mathrm{a}_{0}$ & $a_{1}$ & $\mathrm{a}_{2}$ & $\mathrm{a}_{3}$ \\
\hline & Urban & 36.2 & 30.2 & 12.0 & 0.1 \\
\hline & Suburban & 43.20 & $\begin{array}{l}68.9 \\
3\end{array}$ & 12.0 & 0.1 \\
\hline & Rural & 45.95 & $\begin{array}{l}100 . \\
6 \\
\end{array}$ & 12.0 & 10. \\
\hline $\begin{array}{l}\text { COST } 231 \\
\text { WALFISH- } \\
\text { IKEGAMI }\end{array}$ & \multicolumn{5}{|c|}{ 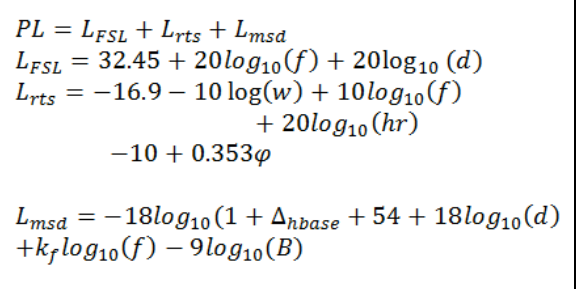 } \\
\hline $\begin{array}{l}\text { d: separation, } \\
\text { gain, } h_{b} \text { base } \\
\text { light, } \varphi \text { is th } \\
\text { height above }\end{array}$ & $\begin{array}{l}\text { equency, } \mathrm{G}_{\mathrm{b}} \text { be } \\
\text { tion antenna he } \\
\text { liffraction angl } \\
\text { lding height, } \\
\text { ldings, w is th }\end{array}$ & $\begin{array}{l}\text { statiol } \\
\Delta_{\text {hbase }} \mathrm{i} \\
\text { is the d } \\
\text { buildin }\end{array}$ & $\begin{array}{l}\text { intenna } \\
\text { eiver h } \\
\text { he tran } \\
\text { tance b } \\
\text { eparati }\end{array}$ & $\begin{array}{l}\text { ain, C } \\
\text { sht, c } \\
\text { itter } \\
\text { ween }\end{array}$ & $\begin{array}{l}\text { receiver } \\
\text { seed of } \\
\text { ntenna } \\
\text { djacent }\end{array}$ \\
\hline
\end{tabular}

Hata-Okumura model was developed for $500-1550 \mathrm{MHz}$. The Cost-231 model extends Okumura-Hata model to frequency range up to $2 \mathrm{GHz}$. The model calculates path loss for urban, suburban and rural areas. The Ericsson model is based on modified Okumura-Hata model and allows changing parameters according to environments. The environment parameters are summarized in parameters is given in table III. Finally, The COST 231 WalfishIkegami model is suitable for flat suburban and urban areas with uniform building height.

\section{Throughput and Adaptive Modulation}

The WiMAX physical layer is based on orthogonal frequency division multiplexing (OFDM). OFDM is an efficient scheme for high data rate transmission in a nonline-of-sight or multipath radio environment. WiMAX supports a variety of modulation and coding schemes and allows for the scheme to change on a burst-by-burst basis per link, depending on channel conditions. The base station uses the channel quality feedback indicator sent by a user to assess downlink quality. Relevant channel-state information fed back by the users can include: Physical CINR, effective CINR and frequency selective subchannel selection. On the uplink, the base station estimates channel quality based on the received signal quality.

The flexibility of the physical layer of WiMAX enables data rate and performance variation based on the operating parameters. Channel bandwidth, the modulation and coding schemes determine the data rate that can be achieved, in addition to other parameters, such as number of sub channels, OFDM guard time, and oversampling rate. The base station scheduler determines the appropriate data rate (or burst profile) for each burst allocation based on the buffer size, channel conditions at the receiver, and user traffic.

The data rate for various channel bandwidths, modulation and coding schemes is shown in table II [20].

TABLE II

WIMAX DATA RATE

\begin{tabular}{|c|c|c|c|c|c|}
\hline \multicolumn{2}{|c|}{ Parameter } & Downlink & Uplink & Downlink & Uplink \\
\hline \multicolumn{2}{|c|}{ System Bandwidth } & \multicolumn{2}{|c|}{$5 \mathrm{MHz}$} & \multicolumn{2}{|c|}{$10 \mathrm{MHz}$} \\
\hline \multicolumn{2}{|c|}{ FFT Size } & \multicolumn{2}{|c|}{512} & \multicolumn{2}{|c|}{1024} \\
\hline \multicolumn{2}{|c|}{ Null Sub-Carriers } & 92 & 104 & 184 & 184 \\
\hline \multirow{2}{*}{\multicolumn{2}{|c|}{$\begin{array}{l}\text { Pilot Sub-Carriers } \\
\text { Data Sub-Carriers }\end{array}$}} & 60 & 136 & 120 & 280 \\
\hline & & 360 & 272 & 720 & 560 \\
\hline \multicolumn{2}{|c|}{$\begin{array}{c}\text { Data Sub-Carriers } \\
\text { Sub-Channels }\end{array}$} & 15 & 17 & 30 & 35 \\
\hline \multicolumn{2}{|c|}{ Symbol Period, $T_{S}$} & \multicolumn{4}{|c|}{102.9 microseconds } \\
\hline \multicolumn{2}{|c|}{ Frame Duration } & \multicolumn{4}{|c|}{5 milliseconds } \\
\hline \multicolumn{2}{|c|}{ OFDM Symbols/Frame } & \multicolumn{4}{|c|}{48} \\
\hline \multicolumn{2}{|c|}{ Data OFDM Symbols } & \multicolumn{4}{|c|}{44} \\
\hline \multirow[b]{2}{*}{ Mod. } & \multirow[b]{2}{*}{ Code Rate } & \multicolumn{2}{|c|}{5 MHz Chamnel } & \multicolumn{2}{|c|}{$10 \mathrm{MHz}$ Channel } \\
\hline & & $\begin{array}{l}\text { Downlink } \\
\text { Rate, Mbps }\end{array}$ & $\begin{array}{c}\text { Uplink } \\
\text { Rate, Mbps }\end{array}$ & $\begin{array}{l}\text { Downlink } \\
\text { Rate, Mlbps }\end{array}$ & $\begin{array}{c}\text { Uplink } \\
\text { Rate, Mbps }\end{array}$ \\
\hline \multirow[t]{5}{*}{ QPSK } & $1 / 2 \mathrm{CTC}, 6 \mathrm{x}$ & 0.53 & 0.38 & 1.06 & 0.78 \\
\hline & $1 / 2$ CTC, $4 x$ & 0.79 & 0.57 & 1.58 & 1.18 \\
\hline & $1 / 2$ CTC, $2 \mathrm{x}$ & 1.58 & 1.14 & 3.17 & 2.35 \\
\hline & $1 / 2$ CTC, $1 x$ & 3.17 & 2.28 & 6.34 & 4.70 \\
\hline & $3 / 4$ CTC & 4.75 & 3.43 & 9.50 & 7.06 \\
\hline \multirow[t]{2}{*}{ 16QAM } & $1 / 2$ CTC & 6.34 & 4.57 & 12.67 & 9.41 \\
\hline & $3 / 4$ CTC & 9.50 & 6.85 & 19.01 & 14.11 \\
\hline \multirow[t]{4}{*}{ 64QAM } & $1 / 2$ CTC & 9.50 & 6.85 & 19.01 & 14.11 \\
\hline & 2/3 CTC & 12.67 & 9.14 & 25.34 & 18.82 \\
\hline & $3 / 4$ CTC & 14.26 & 10.28 & 28.51 & 21.17 \\
\hline & $5 / 6$ CTC & 15.84 & 11.42 & 31.68 & 23.52 \\
\hline
\end{tabular}




\section{EXPERIMENT SET UP}

The design of the experiment is meant to provide flexibility to the students and the instructor. The students can carry the experiments according to their schedule. To obtain the equipments, the department offering the laboratory is encouraged to sign up a memorandum of understanding with service provider. This enables sharing of results and helps answer questions from the network side if needed. Many campuses are often serviced by one or more service providers who will be willing to collaborate on educational projects. The department is expected to sign up for a number of subscriptions for available WiMAX carriers with the understanding that these subscriptions will be used by students to analyze and study the network. During the week of the experiments, the students sign up in groups to borrow the equipments which include: Customer premise equipment (CPE), laptop, and power converter (to power CPE from vehicle outlet).

Depending on the chosen coverage area, the student can choose to collect field data using a vehicle. This ensures large coverage area. Most experiments are expected to be completed in 3-4 hours. The instructor of the lab will determine a safe area either on campus or off campus for students to collect measurements. The locations can be assigned by either map marks on a hard print or landmarks on map software. Depending on the coverage area and network service, the experiments might use a separate CPE or universal serial board (usb) dongle to connect to the network. In the case of a $\mathrm{CPE}$, the equipment can utilize a power converter to supply CPE and laptop devices from the vehicle. The connection of the CPE and laptop is depicted in Fig. 2.

Next, we discuss the procedure and expected results for the objectives laid out in section II:

\section{A. Lab 1 - Cellular Coverage}

This experiment studies the cellular coverage. The procedure requires students to collect data about current serving base station using the CPE webpage (available from manufacturer). The webpage displays identification of current serving base station, as well as other parameters related to the connection as shown in Fig. 3. The students capture both the location and identification over an area that covers several base stations. The students should collect large number of measurements to be able to plot the coverage area of base stations identified.

The students can identify cell border by highlighting locations were CPE interchange between two or more stations.

To complement the field measurements, students can use RF planning tools to generate plots of coverage area as shown in Fig. 4.

The students are expected to contrast and compare the results collecting in the field with those obtained through RF planning tool and explain any differences.

\section{B. Lab 2 - Propagation Models}

The objective of this experiment is to make students become familiar with RF propagation. The students will be able to experience signal degradation as distance from transmitter increases. They will also be able to see the variation of signal power in any locality caused by the environment. After collecting the measurements, the students are expected to generate a graph that shows sig-

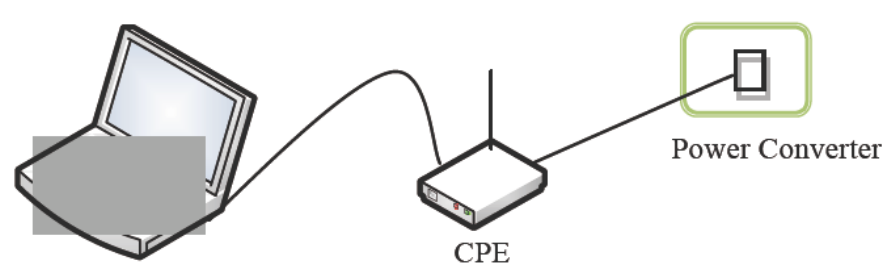

Figure 2. Experiment set up. The CPE uses a power converter plugged into vehicle $12 \mathrm{v}$ outlet.

\begin{tabular}{|c|c|c|c|}
\hline \multicolumn{4}{|c|}{ WiMAX Modem Management } \\
\hline Signal Parameters & Addresses & $\log$ & Advanced \\
\hline \multicolumn{4}{|l|}{ Signal Parameters } \\
\hline \multicolumn{4}{|l|}{ Link Status } \\
\hline \multicolumn{4}{|l|}{ OPERATIONAL } \\
\hline Downlink Parameter & & & Value \\
\hline BS Identifier & & & 000000101430 \\
\hline Downlink Frequency & & & $3547.500 \mathrm{MHz}$ \\
\hline Downlink Channel Bandwidth & & & $5 \mathrm{MHz}$ \\
\hline SNR & & & $15.9 \mathrm{~dB}$ \\
\hline Effective SNR & & & $13.4 \mathrm{~dB}$ \\
\hline Received Signal Strength & & & $-86.4 \mathrm{dBm}$ \\
\hline Modulation & & & QPSK $3 / 4$ \\
\hline
\end{tabular}

\begin{tabular}{l|l|}
\hline Uplink Parameter & Value \\
\hline Uplink Frequency & $3547.500 \mathrm{MHz}$ \\
\hline Uplink Channel Bandwidth & $5 \mathrm{MHz}$ \\
\hline Tx Power & $24.0 \mathrm{dBm}$ \\
\hline Modulation & BPSK $1 / 2$ \\
\hline
\end{tabular}

Figure 3. WiMAX link parameters can be access through web browser by connecting to CPE management server.

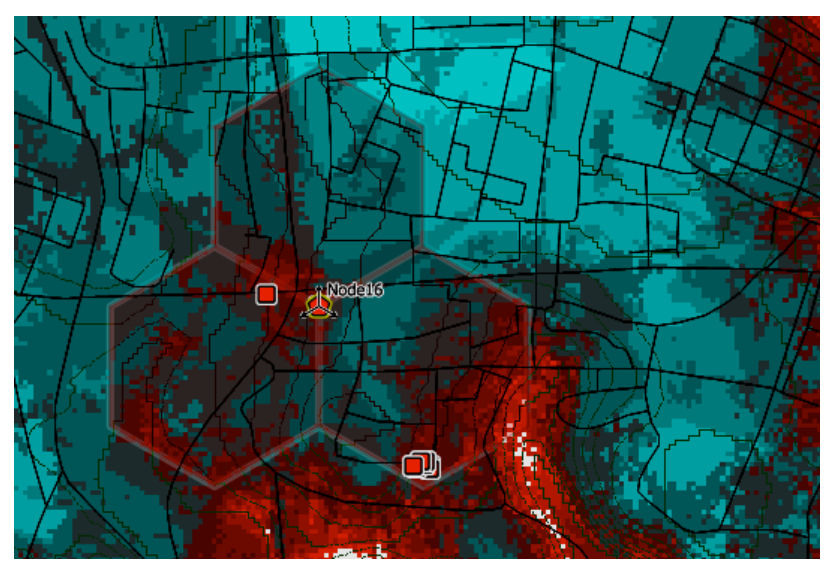

Figure 4. Coverage area prediction using RF planning tool

nal power variation with distance as well as various models used to predict the signals. The students will comment on the applicability of various models and closeness of their fitness to collected data.

The procedure of the experiment is as follows. The team connects the CPE and laptop to power supply. The CPE will attempt to connect to available network. The student will access the configuration page of the link through a browser by entering the CPE webpage. The page displays Received Signal Strength Indicator (RSSI) in $\mathrm{dBm}$ and the current serving base station. The students are expected to complete a table with their location, RSSI, 
and any information about the environment that might interfere with measurement. For each location, the measurement is repeated three times with slight CPE movement. The experiment is completed once all locations data are collected. The experiments can also be conducted with a slight modification. Rather than pre assigning locations for measurements, students are asked to collect measurements at various distance and locations in a coverage area. The students will utilize the base station information in the configuration page to ensure they remain within a coverage area.

After completing the experiment, the students are expected to generate plots of data collected vs. distance and propagation models. A typical graph will look similar to Fig. 5.

The students can also calculate path loss based on base station and receiver gain and loss parameters. The equation below is used to generate Fig. 6 .

$$
P_{R}=P_{T}+G_{T}+G_{R}-L_{T}-L_{R}+P L
$$

\section{Lab 3 - Throughput and Adaptive Modulation}

The throughput and adaptive modulation experiment studies the data rate of the link and its dependence on modulation type. As the channel conditions change, the base station changes modulation to minimize bit errors. When the channel condition is favorable, the base station uses efficient modulation such as 64 QAM for transmission. This enable symbols to carry 6 bits of data. As the channel condition deteriorate, the base station switches to more robust modulation such as BPSK which only carries 1 bit per symbol. The base station uses signal power to assess the channel quality. The variation in signal power can be achieved by considering locations obtained in experiment 2 .

The set up for the experiment is show in Fig. 7. A free software utility (iPerf ${ }^{(B)}$ ) is installed on the server and client sides. The tool supports TCP (Transmission Control Protocol) and UDP (User Datagram Protocol) traffic. To measure downlink throughput, iPerf ${ }^{(\mathbb{R}}$ is run as a client on the laptop and as a server on the server machine. The uplink is measured similarly, however, the client is run on the data server and the laptop is run as server. After iPerf ${ }^{\circledR}$ is run, the tool generates the achievable data rate. The experiment is repeated for different RSSI and results are tabulated. The plot in Fig. 8 shows typical results.

In addition to measuring throughput, students are asked to take note of the modulation used as signal strength changes. The plot in Fig. 9 shows the different modulations used by base station as signal to noise ration changes.

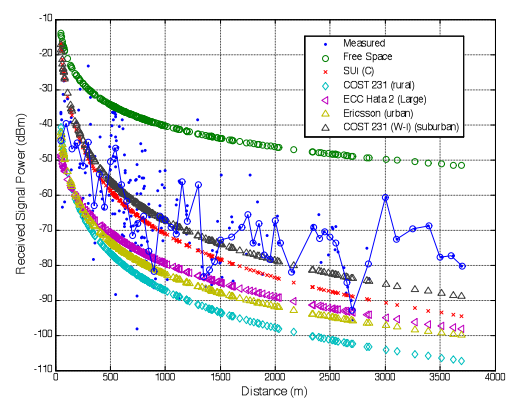

Figure 5. Received signal power vs. distance between transmitted and receiver.

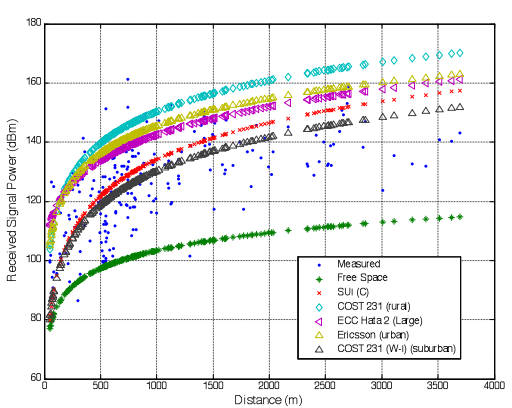

Figure 6. Measured and predicted path loss vs. distance

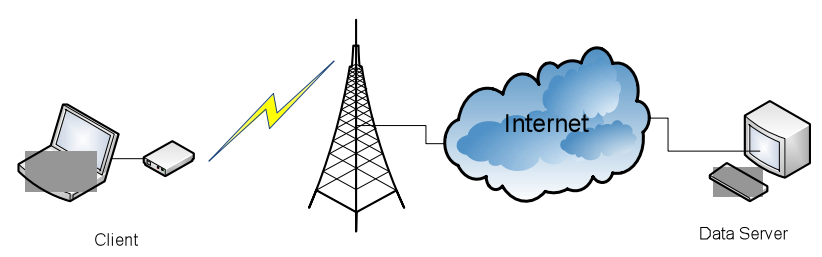

Figure 7. Throughput measurement set up

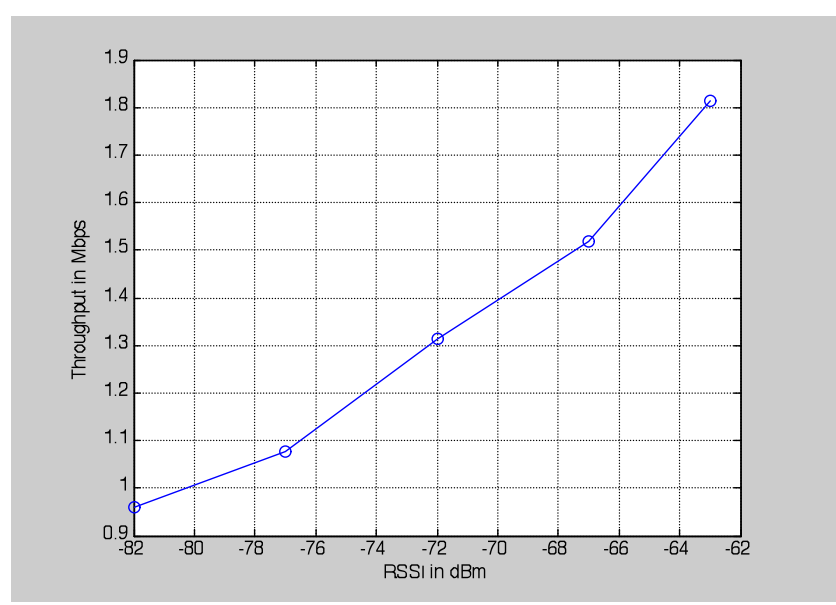

Figure 8. Typical throughput (Mbps) vs. RSSI (dB)

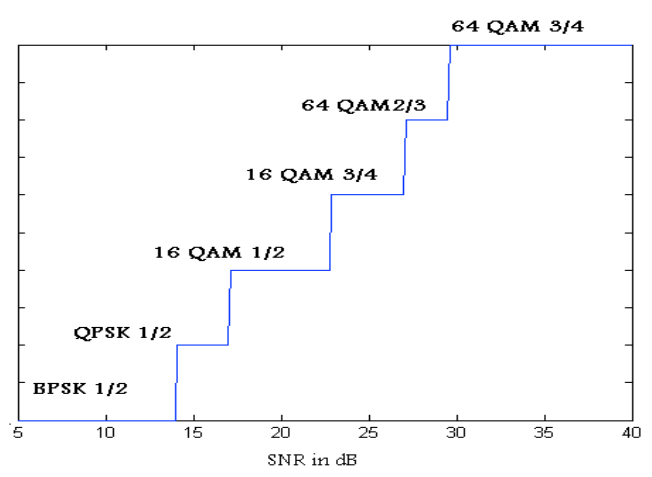

Figure 9. Modulation utilized vs. SNR (dB)

\section{MAPPING COURSE OUTCOMES}

In this section we summarize typical wireless course learning outcomes and map them to experiments and exercises propose in section II. Table III summarizes course outcomes obtained by surveying wireless courses at PSUT and other engineering schools.

By executing the first lab experiments, students are introduced to the cellular concepts. Students can witness firsthand the boundaries of a cell and the carrier frequency 
used in each cell. By mapping field measurements about cell id, students are made familiar with planning and designing of a cellular system. Also using the equipments to obtain measurement familiarize students with WiMAX or the Wireless standards by observing technical terms used to describe different parameters in the measurements.

The exercises in the second lab focus on frequency reuse and propagation models. Students are expected to compare measured signal strength with propagation models to determine and justify the most accurate model.

The third lab familiarizes students with data rate, quality of service, and coding. Students record data rates for different traffic types and channel conditions. Students also record modulation and coding used for various channel conditions.

\section{TABLE III.}

SUMMARY OF COURSE OUTCOMES MAPPED TO EXPERIMENTS

\begin{tabular}{|l|l|}
\hline Course Outcomes & Experiment \\
\hline $\begin{array}{l}\text { Understanding of cellular and frequency reuse } \\
\text { concepts }\end{array}$ & Lab 1, Lab 2 \\
\hline $\begin{array}{l}\text { Understanding of wireless propagation of } \\
\text { Electromagnetic wave and losses }\end{array}$ & Lab 2 \\
\hline $\begin{array}{l}\text { Design and planning of a wireless cellular } \\
\text { system }\end{array}$ & Lab 1, Lab 2 \\
\hline $\begin{array}{l}\text { Radio spectrum allocation in multi-user } \\
\text { systems }\end{array}$ & Lab 1 \\
\hline $\begin{array}{l}\text { Understanding basic issues related to support- } \\
\text { ing } \text { in } \\
\text { data services in cellular networks }\end{array}$ & Lab 3 \\
\hline $\begin{array}{l}\text { Understand how the various signal processing } \\
\text { and coding techniques } \\
\text { combat channel uncertainties }\end{array}$ & Lab 3 \\
\hline $\begin{array}{l}\text { Wireless systems standards } \\
\text { Lab3 }\end{array}$ \\
\hline
\end{tabular}

\section{CONCLUSION}

This paper presented a hands-on low cost wireless communications laboratory based upon deployed broadband wireless network. The experiments are based on several senior projects that studied and analyzed the network performance.

The laboratory allows students to conduct experiments based on real world deployed network. This fosters knowledge of the technology and enables students to contrast and compare theoretical and practical aspects of a wireless network.

Furthermore, the developed lab exercises foster peerlearning as a pedagogical approach. In the future we plan to assess this peer-learning process. In particular, it needs to be investigated is whether peer learning actually occurred, and whether it was effective.

\section{REFERENCES}

[1] IEEE Standard 802.16-2004, IEEE Standard for Local and Metropolitan Area Networks, "Part 16: Air Interface for Fixed Broadband Wireless Access Systems." 2004.

[2] Sarkar, N.I.; Craig, T.M.; , "Teaching wireless communication and networking fundamentals using Wi-Fi projects,"Education, IEEE Transactions on, vol.49, no.1, pp. 98- 104, Feb. http://dx.doi.org/10.1109/TE.2005.858387

[3] Cassara, F.A.; , "Wireless communications laboratory," Education, IEEE Transactions on, vol.49, no.1, pp. 132140, Feb. 2006 http://dx.doi.org/10.1109/TE.2005.863428
[4] Padgett, W.T.; Black, B.A.; Ferguson, B.A.; , "Low-frequency wireless communications System-infrared laboratory experiments," Education, IEEE Transactions on, vol.49, no.1, pp. 4957, Feb. 2006 http://dx.doi.org/10.1109/TE.2005.856150

[5] Linn, Y.; , "An Ultra Low Cost Wireless Communications Laboratory for Education and Research," Education, IEEE Transactions on, vol.PP, no.99, pp.1, 0 ,

[6] Frolik, J.; Weller, T.M.; , "Wireless sensor systems: an approach for a multi university design course," Education, IEEE Transactions on, vol.45, no.2, pp.135-141, May 2002 http://dx.doi.org/10.1109/ TE.2002.1013877

[7] C. Furse et al., "Laboratory project in wireless FSK receiver design," IEEE Trans. Educ. vol. 47, no. 1, pp. 18-24, Feb. 2004. http://dx.doi.org/10.1109/TE.2003.816066

[8] D. Baker, "An innovative project-driven senior-level antennas course," IEEE Trans. Educ., vol. 40, no. 3, pp. 190-194, August. 1997.

[9] J. Milanovic et al, "Comparison of Propagation models accuracy for WiMAX on $3.5 \mathrm{GHz}$," 14th IEEE International Conference on Electronics, Circuits and Systems, 2007. ICECS 2007.

[10] Pasquale Imperatore, Elio Salvadori, Imrich Chlamtac, "Path loss measurements at 3.5 GHz: A trial test WiMAX based in rural environment," Proc. of the 3rd International Conference on Testbeds and Research Infrastructures for the Development of Networks and Communities, 2007. http://dx.doi.org/10.1109/TRIDENTCOM.2007. $\underline{4444709}$

[11] E. Moraes et al, "WiMAX Near LOS Measurements and Comparison with Propagation Models",

[12] T. K. Sarkar et al, "A survey of various propagation models for mobile communications," IEEE Antennas and Propagation Magazine, vol 45, no 3, June 2003, pp. 51-79. http://dx.doi.org/ 10.1109/MAP.2003.1232163

[13] V. Erceg et al, "Channel models for fixed wireless application," Tech. rep. IEEE 802.16 Broadband Wireless Access Working Group, January 2001

[14] Y. Okamura, "Field strength and its variability in VHF and UHF land mobile radio services." Rev. Elec. Comm. Lab. No. 9-10, pp825-873, 1968

[15] Electronic Communication Committee (ECC) with the European Conference of Postal and Telecommunication Administration (CEPT), "The analysis of the coexistence of FWA cell in the 3.33.8 GHz band," tech. rep., ECC Report 33, May 2003.

[16] M. Hata, "Empirical formula for propagation loss in land mobile radio services," IEEE Trans. Veh. Tech. vol VT-29, August 1980, pp. 317-325. http://dx.doi.org/10.1109/T-VT.1980.23859

[17] COST Action 231, "Digital mobile radio towards future generation systems, final report," tech rep., European Communities, EUR 18957, 1999.

[18] Alqudah, Y.A.; Tahat, A.; , "Path loss and propagation models at $3.5 \mathrm{GHz}$ using deployed WiMAX network," Information Networking (ICOIN), 2011 International Conference on, vol., no., pp.301305, 26-28 Jan. 2011

[19] Alqudah, Y.A., "Power Analysis Based on Field Measurements Using 3.5 GHz WiMAX Network", ICOIN 2012, Feb 1-3, 2012, to be published, Bali, Indonesia

[20] Mobile WiMAX - Part I: A Technical Overview and Performance Evaluation, August 2006 [Online]. Available: http://www.wimaxforum.org/technology/downloads/Mobile WiM AX_Part1_Overview_and_Performance.pdf

\section{AUTHORS}

Yazan A. Alqudah is with Princess Sumaya University for Technology, Amman, Jordan, (e-mail: Yazan.a.alqudah@ieee.org.)

Todor Cooklev is with Indiana University Purdue University, Fort Wayne, Indiana.

Received 23 June 2012. Published as resubmitted by the authors 23 September 2012. 